$\begin{array}{lll}\text { KULTURA } & \begin{array}{l}\text { POLSKA A KADEMIA NAUK } \\ \text { KOMITET SOCJOLOGII }\end{array} & \text { ISSN 0023-5172 } \\ \text { i } & \begin{array}{l}\text { INSTYT ST STIÓW POLITYCZNYCH } \\ \text { SPOLECZENSTWO }\end{array} & \\ \text { 2011, nr 2-3 SOCJOLOGIA KULTURY } & \end{array}$

MARCIN KULA

Uniwersytet Warszawski

Akademia Leona Koźmińskiego

\title{
PIENIĄDZ JAKO ZJAWISKO KULTURY
}

Pieniądz jest zjawiskiem bardzo starym, ale — podobnie jak rynek — zmiennym. Nie od razu wykształciła się jego najbardziej znana nam dziś forma. Płacidłem bywały w dziejach bardzo różne rzeczy. U Azteków w transakcjach detalicznych posługiwano się ziarnem kakaowym, przy małych transakcjach tkaninami, a w transakcjach na dużą skalę piórami rzadkich ptaków i złotym proszkiem. W Tybecie i w Afryce $\mathrm{w}$ roli płacideł występowały bryłki soli. We wczesnym okresie kolonizacji Ameryki przez Białych - tytoń. W Polsce wczesnośredniowiecznej - płatki lniane i skórki zwierzęce. W Afryce często spotykanym środkiem płatniczym bywały muszelki cauri. W siedemnastowiecznej Holandii - obrazy, do dziś często nota bene będące jeśli nie płacidłem, to instrumentem tezauryzacji. Zbyteczne dodawać, że często w roli płacideł występowały szlachetne kruszce w różnych formach.

Nawet $\mathrm{w}$ naszym społeczeństwie do dziś pojawiają się płacidła inne niż pieniądze. Zwłaszcza w sytuacjach wyjątkowych płacidłem mogło i może stać się dosłownie wszystko. W warunkach wojennych nieraz stawał się nim chleb. W obozach jenieckich rolę pieniędzy przejmowały papierosy. W Niemczech po wojnie też papierosy królowały jako środek płatniczy. Papierosami nieraz płacono nawet pensje, za papierosy, zwłaszcza amerykańskie, można było kupić bardzo wiele rzeczy. Nawiasem mówiąc, to dlatego żołnierze amerykańscy z samego Berlina wysłali do domu 11 milionów dolarów więcej niż wynosił ich żołd ${ }^{1}$. W latach osiemdziesiątych $\mathrm{w}$ Polsce, gdy wprowadzono kartki na alkohol, częstym płacidłem stała się wódka.

Adres do korespondencji: j.m.kula@uw.edu.pl

1 Tony Judt, Powojnie. Historia Europy od roku 1945, Rebis, Poznań 2008, s. 112. 
Nawet pieniądz, w formie, w jakiej go najczęściej spotykamy, ewoluował. Dawny pieniądz był w gruncie rzeczy towarem, a nie tylko wartością symboliczną. Słowo „bank” wywodzi się od „banca”, czyli ławka czy lada, na której ten pieniądz materialnie leżal. $\mathrm{W}$ procesach toczonych przed sądami w czasach staropolskich sporna suma musiała nieraz leżeć na stole; zabierał ją ten, kto wygrał proces.

Ponieważ pieniądz najczęściej był zrobiony z kruszcu, już sam jego materiał przedstawiał wartość. Nieraz zdarzało się więc, że monety okrawano; jak się okroiło pewną ich liczbę, to się zyskiwało pewną ilość kruszcu. By temu zapobiec, na monetach robiono specyficzne otoczki - zgrubienia bądź żłobkowania na krawędzi. Zwyczajowo przetrwały one na wielu dzisiejszych monetach, mimo iż dziś już nikomu by nie przyszło do głowy okrawać złotówki. Chyba ostatnim, pojawiającym się we wspomnieniach (a więc może podkoloryzowanym!), wypadkiem wykorzystywania naszych monet jako surowca było wyrabianie na przełomie lat pięćdziesiątych i sześćdziesiątych medalików z ówczesnych pięciogroszówek żółto-miedzianego koloru. Koszt surowca wynosił 5 groszy, a więc najpewniej mniej niż kupno surowego metalu i obrabianie go.

Od pieniądza „rzeczywistego” z biegiem wieków przeszliśmy do pieniądza symbolicznego, którego wartość nie wiąże się w żaden sposób z użytym do jego produkcji surowcem. Potem świat przeszedł do pieniądza plastikowego (kart kredytowych). W ogóle ogromna część obrotów pieniężnych oddzieliła się od pieniądza, odbywa się bezgotówkowo. Prawda, że na przykład papiery wartościowe nie są nowością. Pierwsze znane nam weksle pochodziły z XII wieku. Dla naszych czasów charakterystyczne jest jednak to, że człowiek, który przychodzi do banku, chcąc pobrać czy choćby nawet wpłacić grubszą gotówkę, wywołuje zdziwienie - jeśli nie wręcz podejrzliwość.

Swego czasu prawo bicia monety było ważnym atrybutem władzy. Na monetach często zresztą wybijano wizerunek księcia lub króla, co nota bene znakomicie ułatwia dziś datowanie znalezisk. W późniejszych czasach prawo bicia pieniędzy i drukowania banknotów stało się ważnym atrybutem suwerenności państwa. Tylko drukowane przez centralny bank państwa i z jego nazwą banknoty bywały dopuszczane do obiegu jako prawny środek płatniczy. Zdarzały się wyjątki od tej zasady. Część pieniędzy znajdujących się w obrocie w Wielkiej Brytanii z historycznych powodów ma wciąż nadruk „Bank of Scotland”, a część „Bank of England”. Władze komunistyczne w Polsce od lat sześćdziesiątych w praktyce dopuściły dolar jako drugą walutę. Nikt tego na głos nie powiedział, ale faktycznie tak było. Dążenie do przyciągnięcia dolarów było tak duże, iż sieć sklepów „eksportu wewnętrznego” (Baltony, Banku PKO SA, potem przedsiębiorstwa Pewex) stale rozwijano. Nawiasem mówiąc, o Banku PKO SA mówiono wówczas, że jest jedynym bankiem na świecie, który zajmuje 
się sprzedażą rajstop. Ponieważ jednak trzeba było jakoś wybrnąć z sytuacji, wymyślono, że dolary przed użyciem należało zamienić na specjalne „bony”. W praktyce sklepy przyjmowały i waluty wymienialne, i bony, do których w jakiejś proporcji do zarobków mieli prawo również na przykład polscy pracownicy zatrudnieni $\mathrm{w}$ krajach socjalistycznych. Cała zabawa $\mathrm{z}$ „bonami” ratowała teorię, jakoby banknoty emitowane przez NBP były, zgodnie z nadrukiem na nich, jedynym prawnym środkiem płatniczym $\mathrm{w}$ Polsce. W rzeczywistości zielone papierki były dobrem zawsze bardzo w Polsce pożądanym.

$\mathrm{Z}$ czasem na banknotach i monetach umieszczano nie tyle bądź nie tylko postać władcy, ale wyobrażenia ważne z punktu widzenia kraju: herb, postacie znane $z$ historii, elementy narodowej symboliki historycznej. Czasem przez pomieszczenie pewnych osób bądź scen na banknotach i monetach (a niepomieszczenie innych) prowadzono nawet pewną politykę historyczną. Prawda, że więcej osób interesowała i interesuje raczej wartość banknotu niż pomieszczony tam obrazek, ale jest to jeden z najbardziej masowych nośników symboli historycznych. Prezes Banku Narodowego wziął na siebie dużą odpowiedzialność, gdy w 2009 r. bank pominął na przykład postać mjr. Henryka Sucharskiego na monecie poświęconej upamiętnieniu obrony Westerplatte. Mimo późniejszych tłumaczeń trudno uwierzyć, by było to pominięcie przypadkowe.

Brak własnych pieniędzy był na ogół związany z utratą niepodległości. Państwa powstałe w wyniku rozpadu ZSRR, Jugosławii i Czechosłowacji bardzo szybko zadbały o własną walutę - mimo iż szybkość czasem przynosiła ambarasujące rezultaty (jeśli wierzyć prasie, pierwsze litewskie lity, szczęśliwie nie dopuszczone do obiegu, zostały wydrukowane przez firmę specjalizująca się $\mathrm{w}$ produkcji nibypieniędzy dla Disneylandów). Izrael, gdy powstał jako współczesne państwo, nazwał swoją jednostkę monetarną szeklem - bo tak nazywała się składka zbierana przez ruch syjonistyczny w diasporze na koszta odbudowy państwa, poczynając od $1897 \mathrm{r}$.

Obecnie w Europie przekreślono na korzyść euro długotrwałą tendencję historyczną istnienia pieniędzy narodowych. W rysunkach pomieszczonych na pieniądzach motyw narodowy został zachowany tylko szczątkowo. Jest to bardzo wielka zmiana nie tylko $\mathrm{w}$ kategoriach ekonomicznych, ale także $\mathrm{w}$ kategoriach symbolicznych, jakże ważnych z punktu widzenia naszej mentalności.

Znane jest powiedzenie „pieniądz nie śmierdzi”. Pochodzi ono z czasów rzymskich i wiąże się z epizodem, w którym brali udział cesarz Wespazjan i jego syn Tytus. Otóż Wespazjan wprowadził podatek od publicznych latryn. Gromadzony tam w zbiornikach mocz oddawano jako surowiec pomocniczy, stosowany wówczas przy wykańczaniu wełnianych tkanin. Cesarz chciał położyć rękę na dochodach $z$ tego źródła. Gdy syn zaprotestował, ojciec podetknął mu ściągnięte pieniądze pod nos i zapytał, czy śmierdzą. Jako żywo nie śmier- 
działy. Pozostaje jednak faktem, że wielokrotnie w historii ludziom pieniądze w jakimś sensie „śmierdziały”.

Stosunek do pieniądza i obrotu nim był i jest zróżnicowany. Mówi się nieraz o „praniu” pieniędzy - co zakłada, że uzyskane niektórymi drogami są „brudne” (ergo śmierdzące). Pieniądze rozróżniamy w zależności od ich pochodzenia. Zauważono, że zarobione pracą wywołują większy szacunek społeczny niż na przykład wygrane. Znane jest przysłowie: „Grosz zarobiony błogosławiony, grosz wygrany od szatana dany" 2 . Specjalnie traktujemy pieniądze otrzymane z racji niektórych okazji — nie wydajemy ich na "byle co”. Za niektóre usługi (zwłaszcza lekarskie) jeszcze niedawno nie wypadało podać pieniędzy w ręku; pacjent przekazywał je w kopercie przy nibyzażenowaniu przyjmującego. Dawania łapówek na ogół wstydzimy się. Jeśli jednak łapówka jest zakamuflowana w postaci opłaty pośrednikowi lub może być potraktowana jako honorarium za wykonaną przez kogoś pracę, godzimy się z nią łatwiej mimo świadomości istoty rzeczy. Pieniądze otrzymywane za nic w różnych sytuacjach przyjmuje się jako jałmużnę i z przykrymi uczuciami — nawet jeśli nieraz z konieczności przyjmuje się je. To jednak też zależy od konkretnej sytuacji. „Becikowe” przyjmują bez oporów nawet ludzie, którzy uważają (słusznie!) to rozwiązanie za chybione. Natomiast przyjmowanie zapomogi społecznej lub zasiłku dla bezrobotnych - aczkolwiek akceptowane z konieczności - nieraz powoduje przykre uczucia beneficjenta.

Istnieją $\mathrm{w}$ naszej cywilizacji działania, w wypadku których $\mathrm{w}$ ogóle nie aprobuje się rozwiązań z użyciem pieniędzy. Nie wolno opłacać głosów wyborczych ${ }^{3}$. Od dawna nie ma w naszej cywilizacji aprobaty dla handlu ludźmi - aczkolwiek walka o likwidację niewolnictwa była swego czasu trudną epopeją. Warto też pamiętać, że w czasach komunizmu niektóre państwa angażowały się w swoisty handel ludźmi, wyciągając $z$ krajów komunistycznych przedstawicieli swoich mniejszości narodowych i więźniów politycznych (prawda, że czasem bywało to ukrywane w formie kredytów udzielanych państwu komunistycznemu itd.).

Adopcje za pieniądze i przenoszenie cudzej ciąży przez inną kobietę za pieniądze najczęściej są zakazane, ale z pewnością się zdarzają. Nie ma w naszej cywilizacji zgody na handel organami ludzkimi — choć wszystko wskazuje, że ten zakaz jest na różne sposoby naruszany. Krwią zresztą handluje się oficjalnie. Funkcjonują też w naszej cywilizacji na przykład banki nasienia — oddawanego za pieniądze.

W różnych kulturach różnie odnoszono się do pieniędzy. Z jednej strony pieniądz ceniono i ceni się nie tylko dla jego funkcji środka ułatwiającego wymianę

2 Tadeusz Tyszka, Sacrum i profanum $w$ gospodarce, w: Wspótczesne wyzwania nauk praktycznych, Anna Lewicka-Strzałkowska (red.), Wydawnictwo WSPiZ im. Leona Koźmińskiego, Warszawa 2007, s. 55.

3 Tamże. 
dóbr i usług. Ceni się go także w kategoriach symbolicznych. Zauważono, że ludzie, którzy nie mają większych oporów przed przywłaszczeniem sobie na przykład cudzej książki, pieniędzy, choćby o równoważnej wartości, jednak by nie ukradli ${ }^{4}$. Bogactwo ceniono dawniej i ceni się nadal. Jarmark był pozytywną instytucją życia społecznego nie tylko na Bliskim Wschodzie, ale także w naszych rejonach. Rozwijająca się dziś instytucja handlowych deptaków, czy galerii handlowych, jest nawrotem do jarmarku wiejskiego lub małomiasteczkowego, gdzie ludzie spędzali dużo czasu, kupowali w bezpośrednim kontakcie ze sprzedawca, plotkowali, a nieraz znajdowali narzeczone i narzeczonych... w sumie żyli wśród ludzi i nie byli zatomizowani. Anonimowy i atomizujący supermarket już nie przyciąga tylu kupujących co dawniej. Ponowoczesność znalazła odbicie także w tej kwestii.

$\mathrm{Z}$ drugiej strony jednakowoż $\mathrm{w}$ wielu kulturach pojawiało się traktowanie ubóstwa i ograniczenia potrzeb jako swoistego ideału. Nadmierne pożądanie bogactw stało się przyczyną wyszydzenia króla Midasa w znanym micie greckim. Król zażądał od Dionizosa, aby jego dotyk zyskał moc zmieniania wszystkiego w złoto. Pożałował jednak swego życzenia, gdy nawet jedzenie stawało się niestrawnym kruszcem. W innej sytuacji Chrystus wypędził przekupniów ze świątyni.

Prawda, że w średniowieczu waga była jednocześnie instrumentem służącym do ważenia towarów i (w symbolice) grzechów człowieka przy opuszczaniu przezeń tego świata, a targi często zbiegały się $\mathrm{w}$ czasie $\mathrm{z}$ obrzędami kościelnymi. Nieraz lokowano je przy świątyniach ze względów bezpieczeństwa. Sam kult ze swymi pielgrzymkami, ofiarami, odpustami grzechów, wyprawami krzyżowymi, budową świątyń itd. wywoływał w końcu spore przepływy finansowe. Niemniej jednak w naszej cywilizacji zawsze istniało jakieś przełamanie pomiędzy religią a pieniędzmi. Nieraz pojawiała się w naszym kręgu cywilizacyjnym przeciwstawna istocie rynku idea sprawiedliwej ceny i usprawiedliwionego zysku — przy czym wielokrotność dążeń do znalezienia takich rozwiązań dobitnie świadczyła, iż ludzie nigdy nie byli usatysfakcjonowani istniejącą rzeczywistością.

Może w związku z referowaną tradycją zajęcia związane z obrotem pieniężnym często wzbudzały niechęć. Ceniono wojaczkę z jednej strony, a zajęcia produkcyjne, najlepiej uprawę roli, z drugiej. Szlachcic mógł świecić bogactwem i starał się je robić - ale nie wolno mu było zajmować się handlem pod groźbą utraty szlachectwa. Stan mieszczański marnie się u nas rozwijał dlatego, że gospodarka folwarczno-pańszczyźniana podcinała miasta - ale również dlatego, $\dot{z}$ e mieszczanie nie byli cenieni i ograniczano ich prawa. W pewnych okresach nie mogli nawet ubierać się tak jak szlachta - by nie było wątpliwości, kto jest kim. Pieniądz był postrzegany jako coś niedobrze niewolącego. W końcu

\footnotetext{
4 Tamże.
} 
XIX wieku jedna z emigrantek pisała z Nowego Jorku do rodziców, do nieznanej miejscowości na północnym Mazowszu:

„Ach jak to tęskno, tu się słyszy tylko chałas, tysiące idących ludzi, gwizd fabryk, dzwonki tramwajów, gwizd chandlarzy i to w miejsce słowików i skowronków, w miejsce róż, tulipanów, bzów, beczki śmieców, wozy z dachami, smród jak powietrze. Są słowiki, kwiaty, ale trzeba iść daleko do ogrodów, a kto za czas zapłaci?" 5

Zajęcia związane $z$ obrotem pieniężnym przerzucano często na nie cieszących się estymą Żydów, którym bardzo trudno było przejść do innych zawodów. Zwrotnie zwiększano $\mathrm{w}$ ten sposób wyizolowanie tej grupy w społeczeństwie, gdyż mało kto lubi, a przynajmniej mało kto wtedy lubił, ludzi zajmujących się obrotem pieniężnym lub (i) handlem. Z czasem licząca się część grupy żydowskiej uwierzyła, że zajmowanie się pieniędzmi i handlem jest czymś złym. Ruch syjonistyczny marzył o przekształceniu Żydów-handlarzy z Nalewek w Żydów-rolników w Palestynie. Po latach pojawił się smętny żart, że role Polaków i Żydów się odwróciły: jak wpierw Polacy byli żołnierzami, a Żydzi handlarzami, tak za realnego socjalizmu Żydzi stali się żołnierzami (w Izraelu), Polacy zaś handlarzami (przy okazji wycieczek „turystycznych”). W Polsce, gdzie w jakimś stopniu trwa negatywny stereotyp Żyda, elementem owego stereotypu jest wciąż „siedzenie na pieniądzach”. Całkiem niedawno, w 2007 r., w Niechorzu (zachodniopomorskie), w budce ze śmieciem dla turystów, która znajduje się naprzeciwko licznie odwiedzanej latarni morskiej, za całe 10 zł kupiłem wykonany w lokalno-wakacyjno-bazarowym stylu, leżący obok Jana Pawła II, koni i fal morskich, oprawiony obrazek Żyda. Wymalowany jest na nim liczący pieniądze Żyd z zaakcentowanymi cechami uznawanymi za semickie. Napis, stanowiący część obrazka, głosi: „Żydek [!] w sieni, pieniądze w kieszeni”. Jeszcze później taki sam obrazek (pewno seryjna produkcja!) widziałem w jednej $z$ pierogarni $\mathrm{w}$ Warszawie.

Tak naprawdę to chyba dopiero dziś, może $\mathrm{w}$ związku z przemianą typu pracy związanej z obrotem pieniężnym, na całym świecie znika negatywnie zabarwiony stereotyp przedstawiciela tej profesji. W wielu krajach małe sklepiki, ze sprzedawcą wyposażonym w liczydła, i marne kantory zostały zastąpione przez współczesne sklepy i banki obsługiwane z pomocą elektroniki. Zatrudniony w nich personel nie przypomina już dawniejszych lichwiarzy i handlarzy. Tych ostatnich, jeśli przetrwali, wciąż jednak nie dopuszcza się do porządnych budynków i miejsc.

Nieco inaczej przedstawiały się omawiane sprawy w krajach głęboko przeoranych przez Reformację. Protestantyzm nie toleruje wprawdzie puszenia się bogactwem, nie lubi ani bogatych strojów, ani tym bardziej strojnych kościołów

${ }^{5}$ Listy emigrantów z Brazylii i Stanów Zjednoczonych. 1890-1891, Witold Kula, Nina Assorodobraj-Kula, Marcin Kula (red.), LSW, Warszawa 1973, s. 403, list 230 (zachowana pisownia oryginału). 
- ale nie ma nic przeciwko robieniu pieniędzy, obracaniu nimi, inwestowaniu ich. Na holenderskich obrazach występują czarno ubrani mieszczanie i ich surowo ubrane, pod szyję zapięte małżonki - ale pod ścianą nieraz stoi skrzynia, która pozwala się domyślać obfitej zawartości, a przez okno widać kołyszące się na morzu statki, których przynależności do osoby z portretu nietrudno się domyślić.

Występujący w znacznej części naszej cywilizacji stosunek do pieniądza jako do czegoś złego przejął niejeden ruch utopijny i, z czasem, ruch socjalistyczny i komunistyczny (skądinąd też mające cechy ruchów zmierzających do realizacji utopii). Może warto w tym kontekście przypomnieć przedstawienie Skrzypek na dachu. W jednym z epizodów owego musicalu młody socjalista rzuca pod adresem Tewje-mleczarza: „Pieniądze są plagą ludzkości!” (Tewje zwraca na to twarz ku Niebu i woła: „Panie Boże, spuść na mnie więcej tych plag!”). Konsekwencją postawy reprezentowanej przez owego młodego człowieka i cały jego ruch było swoiste odwrócenie się od pieniędzy w socjalistycznej przemianie. Biedni byli dobrzy — jak sankiuloci w Rewolucji Francuskiej — bogaci zaś co najmniej podejrzani (poza, rzecz jasna, przywódcami przemiany, którzy nieraz potrafili z czasem zadbać o dobra doczesne, ale z natury rzeczy pozostawali poza podejrzeniami). Kupcy i bankierzy byli chyba jeszcze gorsi niż fabrykanci. Tak zwana bitwa o handel, przeprowadzona w Polsce w 1947 r., a polegająca na zniszczeniu ogromnej części prywatnego kupiectwa, realizowała zadanie niewiele mniej ważne $z$ punktu widzenia systemu niż nacjonalizacja przemysłu i reforma rolna.

W koncepcji komunistycznej „skok do królestwa wolności” miał polegać na wyzwoleniu się z dominacji rynku i pieniądza. Planowa organizacja produkcji i dystrybucji (a więc też konsumpcji) miała zastąpić aktywną rolę pieniędzy ${ }^{6}$. W realnym socjalizmie, wbrew przewidywaniom Marksa, nie zaniknęły one wprawdzie, ale rzeczywiście nie przewidziano dla nich roli aktywnej. Już samo ich istnienie miało być jednak upiększone zamieszczeniem rysunków o tematyce świata pracy i produkcji na banknotach (rolnik, rybak, dymiące śląskie kominy...). Ludzi do pracy miała motywować radość twórcza, chęć działania dla społeczeństwa, plan, czasem oczywiście także sankcje różnego typu... a nie jakoby brudny motyw zysku. Różne ułatwienia życiowe miały być dostarczone ludziom za darmo lub prawie za darmo (mieszkania, stołówki, wczasy). Ceny, płace i dochód teoretycznie starano się wyprowadzić z podstawowej wartości, za jaką uznawano pracę ludzką. Podświadomie nawiązywano w ten sposób do utopijnej koncepcji „sprawiedliwego zysku”, ale w praktyce wyznaczano je

\footnotetext{
${ }^{6}$ Andrzej Walicki, Idee i ludzie. Próba autobiografii, Instytut Historii Nauki PAN, ASPRA-JR, Warszawa 2010, s. 345-346.
} 
w dużym stopniu arbitralnie. Czasem w rozliczeniach pomiędzy krajami RWPG przyjmowano pewną skalę punktową. Na przykład w rozliczeniach usług turystycznych przyjmowano, że zaprowadzenie jednego uczestnika wycieczki zagranicznej do teatru odpowiada pewnej liczbie punktów, a dzień pobytu nad morzem innej. Był to w pewnym sensie powrót do formuły wymiany „towar za towar" - tyle że w ułatwionej formie. Z czasem przy wyznaczaniu cen niekiedy zaczęto wzorować się (o zgrozo!) na zachodniej skali wartości.

Samo słowo „zysk” zostało wyklęte w gospodarce socjalistycznej. Poza wszystkim walka o zysk prowadzi do nierówności. Komunizm dziedziczył natomiast w tym zakresie odwieczne ludzkie marzenie o równości. Konkretnie dziedziczył marzenie Rewolucji Francuskiej o równości. Jej marzyciele mówili:

„Il faut raccourcir les géants

Et faire les petits plus grands

Tous à la même hauteur

Voilà le vrais bonheur" 7 .

Gdy w 1962 r. charkowski ekonomista Jewsiej Liberman zaczął ponownie używać słowa „zysk”, stało się oczywiste, że opoka, na której stał Związek Radziecki, zaczyna się chwiać. Ówczesne trzęsienie ziemi okazało się jednak ograniczone i szybko ustało. Brzydkie słowo ponownie ustąpiło wszechpotężnemu planowi. Planowały i plan wykonywały (przynajmniej na papierze) nawet instytuty humanistyczne Polskiej Akademii Nauk, wpisując na odpowiednich formularzach wiekopomne dzieła do napisania w kolejnych kwartałach. W moim kręgu tylko jedna osoba, dzisiejszy profesor Jerzy Jedlicki, zapytał, czy na następny kwartał może wpisać myślenie jako zadanie dla siebie. Odpowiedziano mu nota bene negatywnie. Bystrzejsi ludzie na mieście pytali, czy Miejskie Przedsiębiorstwo Pogrzebowe też winno wykonywać i przekraczać plan.

Najpełniejsze wnioski z niechęci do pieniądza wśród krajów obozu wyciągnęła Kuba. Che Guevara był tam autorem koncepcji, w myśl której człowiek winien być motywowany do pracy moralnie, a nie materialnie. Na Isla de Pinos, nazwanej w nowej nomenklaturze Wyspą Młodości, budowano rzekomo szczęśliwe społeczeństwo ludzi młodych, wśród których pieniądz miał już być wyłącznie resztówką na podobieństwo wyrostka robaczkowego. Bitwę o handel też przeprowadzono na Kubie.

Skutki tych wszystkich pomysłów były gorsze niż fatalne. Jak swego czasu zauważono, w zestawieniu $z$ kapitalizmem komunizm nie poprawił racjonalności gospodarowania w skali makro, a zlikwidował ją na poziomie mikro. Wyścig, w którym podstawowym instrumentem były pieniądze, zastąpił wyścigiem protekcji w dążeniu do uzyskania dóbr rzadkich i swobodnym uznaniem osób

7 „Trzeba zmniejszyć wielkoludów / a powiększyć tych, co nie urośli / Pełne szczęście zapanuje / przy wszystkich o tej samej wysokości”. Zwrócenie uwagi na te słowa zawdzięczam dr Krystynie Zienkowskiej. 
decydujących o możliwości ich uzyskania przez petentów. W porównaniu z takim wyścigiem konkurencja legalnie zarabianymi i wydawanymi pieniędzmi niewątpliwie była uczciwsza. W moim polu widzenia pewien stary komunista, jeszcze z pewnością ideowy, swego czasu odrzucił możliwość wykupienia domu, w którym mieszkał - możliwość, jaką on akurat miał. Powiedział, że nigdy nie był i nie będzie kamienicznikiem (jeden z symboli zła w eksploatowaniu ludzi przez ściąganie $z$ nich pieniężnego haraczu!). To, że przez lata mieszkał za darmo w domu zabranym pierwotnemu właścicielowi, jakoś mu nie przeszkadzało.

Konkretnie na Kubie z fazy gospodarki towarowo-pieniężnej, którą ten kraj już kiedyś w swej historii osiągnął, szybko pozostały jedynie pieniądze. Wszystko zaczęło podlegać racjonowaniu bądź rozdzielnictwu przez związki zawodowe i zakłady pracy. Kraj stał się jednym z niewielu na świecie, gdzie przybysz mógł wyjść rano $z$ hotelu bez portmonetki - gdyż i tak był pewien, że towarów, nawet w postaci najprostszej bułki w sklepie, na swojej drodze nie napotka. Może nawet teorię o wadze bodźców moralnych akcentowano tym bardziej, im mniej sensu miało płacenie pieniędzy za pracę $\mathrm{w}$ sytuacji powszechnych braków zaopatrzenia. Prawda, że przyjęta teoria nie była jedyną przyczyną zniknięcia bułek i tysięcy innych artykułów ze sklepów. Jednak i owa teoria, przynajmniej zwrotnie, braki pogłębiała. Niejedna Kubanka mogłaby uczynić swoim zdanie $z$ funkcjonującego kiedyś u nas dowcipu o Marksie, w myśl którego matka mu jakoby powiedziała: „Karolu, jaka szkoda, że zamiast analizować kapitał nie zająłeś się jego robieniem!”.

Spoza krajów bloku, które powoływały się na ideologię komunistyczną jako zasadę swego działania, w niechęci do pieniądza pobiła wszystkich Kambodża Czerwonych Khmerów. Nie było to jednak niczym nadzwyczajnym, skoro zanegowano tam funkcjonowanie rodziny, własność prywatną, zlikwidowano samochody, telefony, miasta, wyeliminowano elektryczność, książki, kalendarze, archiwa, dokumenty i zabytki... w sumie wyeliminowano wszystko, co tradycyjne bądź co zachodnie — oraz kilka milionów ludzi.

Komunizm nie był jedynym współczesnym ruchem niechętnym bogactwu i pieniądzom. Kibuce w odradzającym się swego czasu Izraelu powstawały jako egalitarystyczne gminy bezpieniężne. Bunt studentów paryskich w maju 1968 r. niósł hasła odwrócenia się od cywilizacji konsumpcyjnej, a więc w sumie od idei robienia pieniędzy jako nadającej sens życiu. Ówcześni studenci paryscy mogliby łatwo uczynić swoimi słowa „Pieniądze są plagą ludzkości!”.

Z czasem w większości krajów komunistycznych zaczęto życzliwiej patrzeć na pieniądze i bodźce materialne. Komunizm obrastał w piórka, tracił wiele cech wynikających z projektu ideologicznego, a jednocześnie nie mógł sobie dać rady z gospodarką. W Polsce za późnego Gomułki zaczęto mówić o potrzebie intensyfikacji bodźców materialnego zainteresowania. Gierek już wprost rzucił hasło „Polacy bogaćcie się!” - nawet jeśli nie użył tych słów. Wielka Polska („druga Polska”) miała być zbudowana przez Polaków motywowanych 
do pracy perspektywą zdobycia małego samochodu. Szczytem tej ewolucji było (mówiąc z przymrużeniem oka!) powiedzenie pracownikom humanistycznych instytutów Polskiej Akademii Nauk, że mają wytwarzać zysk. Zysk ów powstawał rzekomo przez to, że pracownicy wytwarzali produkty intelektualne, które kupował Sekretarz Naukowy PAN, skądinąd utrzymujący owe instytuty poprzez przyznawanie im środków do życia z budżetu państwa. Nikt nie mógł $z$ tego nic pojąć poza rozumieniem, że bierze się udział w grze pozorów, jeśli nie wręcz w teatrze absurdu. Co charakterystyczne, nawet gdy słowo „zysk” przestało być wyklęte, starano się podkreślać, że w socjalizmie ma ono inne znaczenie niż w kapitalizmie; jednakowoż chyba tylko bizantynolodzy potrafili wczuć się w taką subtelność.

Skończyło się to wszystko ponownym swoistym odwróceniem się od pieniędzy — gdy zamiast „drugiej Polski” zbudowaliśmy „trzeci świat”, gdy zakłady pracy starały się wymieniać towary na towary, ludzie zaś bardziej cenili zdobyte produkty niż pieniądze. Rola ogonków do sklepów w realnym socjalizmie zarówno tych nieustających po mięso, jak i tych po wszystko ze schyłkowego okresu formacji - jest obecnie badana przez historyków; była bardzo bogata i wielostronna. Podobnie badane są strategie stosowane przez ludzi dla zdobycia zaopatrzenia - włącznie z powstawaniem rodzinnych „siatek zaopatrzeniowych" i zaistnieniem niezaplanowanych przez władze wtórnych transferów dóbr ${ }^{8}$. W końcu, $\mathrm{w}$ myśl dowcipu $\mathrm{z}$ tych czasów, w komunizmie każdy miał mieć wszystko... i helikopter. Po co helikopter? Bowiem gdyby ktoś się dowiedział, że w jakimś innym mieście „podrzucono” (słowo charakterystyczne!) skarpetki, to wsiadałby w helikopter i leciał po nie.

Dziś z komunizmu już wiele nie pozostało. Istnieją oczywiście bardzo wielkie komunistyczne Chiny, ale wszystko wskazuje na to, że nawet one polubiły pieniądze. W świecie zachodnim obroty pieniężne przynoszą dziś zdumiewająco wielką część dochodu w porównaniu do produkcji materialnej dóbr ułatwiających ludziom życie. W zdumiewająco wielkim stopniu zarabia się na obrocie pieniężnym, a nie na handlowej wymianie dóbr. Atrakcyjność obrotu pieniężnego wręcz odciąga inwestorów od zainteresowania sferą produkcji. Nic nie wskazuje na to, żeby w bliskiej przyszłości ponownie miał pojawić się ktoś i powiedzieć, że to nie ma sensu - choć najpewniej nie ma. Nie da się natomiast wykluczyć, że za jakiś czas ci, których zwycięska droga rozwoju pozostawi pod kreską - a tacy są i będą liczni - powiedzą, że chcą coś jeść i w czymś mieszkać, a więc chcą rozwoju wytwórczości i dostępności dóbr, a więc w konsekwencji wystąpią przeciw tym, którzy nie tylko jedzą i mieszkają, ale także bogacą się dzięki obracaniu pieniędzmi. W 2010 r. włoski artysta Maurizio Cattelan przed giełdą w Mediolanie ustawił wyprostowany środkowy palec wykuty w marmurze. Nie da się wykluczyć, że nie tylko artysta uczyni kiedyś taki

\footnotetext{
${ }^{8}$ Małgorzata Mazurek, Społeczeństwo kolejki. O doświadczeniach niedoboru 1945-1989, Europejskie Centrum Solidarności-Trio, Warszawa 2010.
} 
gest pod podobnym adresem. Swego czasu, w 1997 r., demonstrujący robotnicy niemieccy nieśli już hasła „Akcji się nie je”. Czy było to demagogiczne? Niewątpliwie. Groźne? Także. Z niejednej demagogii wyniknęły już nieszczęścia dla świata. Demagogia jest jednak nie tylko dziełem demagogów; oni muszą mieć warunki, by ich hasła były podejmowane.

Istnieje powiedzenie, że kapitalizm to taki ustrój, w którym za pieniądze można mieć wszystko - $z$ honorem włącznie. Zostawmy na boku, czy jest ono prawdziwe. Zastanówmy się natomiast, czy wszystkie dziedziny życia winny być regulowane pieniężnie bez zastrzeżeń? Czy sfera pieniądza powinna być sferą wszechogarniającą? W pewnym sensie ona nie może taką nie być — skoro pieniądze tkwią $\mathrm{w}$ zasadzie $\mathrm{w}$ każdym elemencie naszej aktywności, jak krew w każdym fragmencie naszego ciała. Milton Friedman miał rację, gdy powiedział, że „nie istnieje coś takiego jak darmowe obiady”. Nawet za „darmową" zupę ktoś wszak zapłacił, a najczęściej po prostu podatnik. Z praktyki wiadomo też, że to, co przychodzi łatwo i za darmo, równie łatwo jest marnotrawione miast szanowane.

Pytanie o zakres sfery, w której na co dzień funkcjonujemy motywowani pieniędzmi, jest jednak zasadne. Warto przypomnieć, że nawet w kapitalizmie relatywnie najdoskonalszym istnieje coś takiego jak sfera usług publicznych. Odpowiedź na pytanie, jak winna być ona rozległa, nie jest przesądzona z góry.

„Doświadczenie krajów zwanych socjalistycznymi - pisze Andrzej Walicki przyznało rację liberałom, dowiodło bowiem, że realizacja komunistycznej idei wyzwalania społeczeństwa spod władzy ślepych, urzeczowionych sił rynku prowadzi do zniewolenia totalnego, łączącego represywne cechy teokracji, feudalizmu i centralistycznej dyktatury. Wielkim nadużyciem było jednak interpretowanie tego zwycięstwa jako przyznania bezwzględnej racji ideologii integralnie wolnorynkowej, domagającej się demontażu demokratycznego kompromisu w postaci ograniczenia wszechwładzy rynku przez instytucje społeczne i państwowe, reprezentujące (w terminologii Marksa) władzę osób nad urzeczowionymi relacjami, a nie odwrotnie" ${ }^{9}$.

Po epoce zwiększania sfery usług publicznych i zwiększania zaangażowania państwa w życie społeczne - bynajmniej nie ograniczonej do systemu komunistycznego - przyszły czasy, gdy po trosze wszędzie prywatyzujemy i komercjalizujemy instytucje wpierw uznawane za część sfery publicznej (z pocztą, drogami, kolejami i więzieniami włącznie). Jest to bardzo dyskusyjne. Wypada postawić pytanie, gdzie jest sensowna granica działania w tym kierunku? Czy dojdziemy do prywatyzacji armii i urządzeń wojskowych? Na etapie komercjalizacji wielu dostaw wojskowych już jesteśmy — ale można pójść dalej. W końcu

\footnotetext{
${ }^{9}$ Andrzej Walicki, Idee i ludzie, cyt. wyd., s. 359-360.
} 
w dawniejszych czasach bywały wojska zaciężne, które, jako w pewnym sensie zawodowe, nawet nieźle się biły. Dziś w niejednym kraju „peryferyjnym” też występują takie prywatne armie. Jeśli jednak pójdziemy jeszcze dalej w tym kierunku, to może będzie wypadało skomercjalizować niektóre agendy rządowe? W niektórych wypadkach nie jesteśmy już daleko od tego. W Polsce w 2010 r. raport o stanie szkolnictwa wyższego przygotowała wynajęta firma (Ernst \& Young). Pomińmy, że w odczuciu wielu z nas takie wnioski mogłoby przedstawić samo nasze środowisko za mniejsze pieniądze. Pomińmy, że - co oczywiste - jednak zawsze dobrze jest mieć oceny z kilku źródeł, a więc także ze źródła zewnętrznego. Powstaje jednak pytanie, do czego właściwie służy odpowiednie ministerstwo oraz właściwe instytuty badawcze?

W krajach postkomunistycznych płaci się obecnie nawet za przyjemności takie jak wejście na Świnicę (dlaczego nie za przejście po Marszałkowskiej?). Latem 1993 r. polska prasa donosiła, że gdy obok stacji kolejowej w Wawrze znaleziono niewypał w postaci pocisku artyleryjskiego z czasów wojny, to robotnicy odmówili usunięcia go, gdyż bali się - wojsko zaś dlatego, iż nie było jasności, kto za tę usługę zapłaci. W konsekwencji pocisk zasypano, kierując się założeniem, iż skoro nie wybuchł przez pół wieku, to pewno nie wybuchnie i dłużej. Trudno powiedzieć, czy później ktoś poszedł po rozum do głowy. W trakcie pertraktacji polsko-niemieckich przeliczono na pieniądze straty materialne Warszawy podczas drugiej wojny światowej (co zapewne miało być odpowiedzią na postulaty odszkodowań za mienie utracone przez Niemców). Pojawił się jednak także pomysł przeliczenia na pieniądze życia ludzkiego utraconego podczas wojny i przemnożenia przez szacunkową liczbę ofiar. Ekipa przygotowująca ten materiał odmówiła takiej operacji. Stało się szczęśliwie, bo przecież ktoś mógłby jeszcze wymyślić dalszy absurd: chcieć doliczyć straty demograficzne powstałe na skutek nienarodzenia się dzieci ludzi, którzy zostali zabici, nim je zdążyli mieć (no i doliczyć straty w kolejnych pokoleniach).

Prawda, że można tę sprawę skomplikować. W końcu w naszej cywilizacji odszkodowania za cierpienia, śmierć bliskich, wykorzystywanie darmowej pracy przymusowej są płacone. Postulaty w tym zakresie szybko przyrastają. Dotyczą już nie „tylko” na przykład odszkodowań dla osób cierpiących i takich, które straciły bliskich w wyniku Holokaustu, ale dla potomków niewolników za pracę ich przodków, jak również dla krajów afrykańskich, z których brano owych niewolników. Postuluje się, by Francja zwróciła Haiti pieniądze, które wymogła na wyzwalającym się państwie za zniszczenie francuskich plantacji podczas tamtejszej rewolucji wolnościowej. Haiti słono płaciło Francji z tytułu tego zobowiązania w długich latach $1825-1947^{10}$. W wielu wypadkach zamiast o odszkodowaniach i zwrotach po latach, czy nawet wiekach, należałoby jednak raczej mówić o udzieleniu pomocy w dziele pokonania biedy

10 Mariusz Piotrowski, Francjo, oddaj Haiti 17 mld euro, „Gazeta Wyborcza”, 17 sierpnia 2010. 
grupy społecznej lub kraju, powstałej między innymi na skutek dawnych działań, czy o wynagrodzeniu specyficznych trudności, które spotkały dany kraj lub grupę. Lepiej byłoby rzecz załatwiać właśnie nie na płaszczyźnie handlowego rachunku.

Można zapytać, czy każde miejsce w mieście powinno zostać sprzedane za pieniądze w ramach dzikiej gospodarki. Przestrzegają przed tym doświadczenia dziewiętnastowiecznych miast europejskich, a także na przykład współczesnych metropolii Ameryki Łacińskiej (vide na przykład zawojowanie przez nowoczesne São Paulo dawnej dzielnicy Jardims). Także jednak doświadczenia niektórych, obecnie szybko rozbudowujących się dzielnic Warszawy.

Można zapytać, czy każdy zabytek winien być przerobiony przez dewelopera. Oczywiście, skoro chcielibyśmy zachować jak najwięcej z nich, to dla większości trzeba znaleźć zastosowanie inne niż muzealne. Po prostu nawet zabytkowe obiekty muszą na siebie pracować. Utrzymanie niektórych byłoby tak drogie, że nie sposób pokryć kosztów jedynie z budżetu państwa (zwłaszcza gdy ich wartość historyczna lub symboliczna jest ograniczona). Przykładem dawne obiekty przemysłowe lub wojskowe (na przykład twierdza w Modlinie!). W takich wypadkach wypadałoby jednak nałożyć szczególne obowiązki na dewelopera. Nadto, a może na pierwszym miejscu, zabytki cenne artystycznie, historycznie oraz z powodu swej wagi symbolicznej nie powinny mimo wszystko podlegać komercjalizacji. Nie ma żadnych argumentów przeciwko wynajmowaniu sal na różne cele przez Wawel czy przez Zamek Królewski w Warszawie. Nie wszystkie dobra kultury jednak mogą i powinny być dochodowe. Muzeum Narodowe musi mieć zapewnione podstawowe finansowanie, a same opłaty za bilety w żaden sposób nie wystarczą.

Za oddawane sobie nawzajem usługi rozliczają się obecnie między sobą wydziały tych samych wyższych uczelni, skądinąd wciąż noszących nazwę uniwersytetów, sugerującą jedność. Dziś już nie pyta się, czy artykuł wieńczący badania jest dobry, czy zły, lub o to, jakie jest czasopismo. Periodyk jest dobry, gdy daje punkty. Redakcje wręcz reklamują swoje pisma wobec autorów dyskretnym napomknieniem, że „publikacja u nas przynosi x punktów”. Pracownicy są dobrzy, gdy zdobywają punkty, bo to przysparza ich placówce pieniędzy.

Łatwo doprowadzić oświatę do sytuacji, w której nawet w zakresie podstawowej normy lepsze wykształcenie dla dzieci będzie miał ten, kto więcej zapłaci. Ze sportu zrobiliśmy imprezę komercyjną, a ze sportowców ludzi do wynajęcia za grube pieniądze (zwycięża ten, kto „kupi sobie” lepszych sportowców, nie mówiąc już o głośnym ostatnio w Polsce „kupowaniu meczy”). Czy dojdziemy do porównywania kosztów wychowania dzieci z kosztami utrzymania starych rodziców i sugerowania dorosłym dzieciom, że powinny zajmować się rodzicami dlatego, że rodzice $\mathrm{w}$ nie kiedyś zainwestowali?

Mniej więcej podobne obserwacje można sformułować na temat lekarzy, szpitali i leczenia. Łatwo można zmienić produkcję i dystrybucję lekarstw w jeden wielki biznes i jedynie biznes. Łatwo można — co jest dramatycznym ab- 
surdem — nie wykorzystywać części potencjału medycznego z braku pieniędzy. Przy przesadnym myśleniu o pieniądzu łatwo nie zauważać dramatu moralnego w niektórych decyzjach medycznych czy z zakresu bezpieczeństwa pracy, dyktowanych rachunkiem ekonomicznym. Lekarka, która została ukarana przez sąd za przekroczenie kosztów leczenia ustalonych przez NFZ, dramatycznie mówiła dziennikarce:

„Fundusz odmówił zapłaty szpitalowi, a szpital uznał, że to ja, ordynator onkologii, mam wyrównać tę stratę. A także zwrócić za pacjentów, za których fundusz zapłacić nie chciał, bo widocznie uznał, że droga, nowoczesna terapia, którą zastosowałam, nie była uzasadniona - tylko o kilka miesięcy przedłużała życie chorym. W sumie 90 tys. zł. Ani przez moment nie sądziłam, że mogę przegrać ten proces. Moje pokolenie wychowano w przeświadczeniu, że środki finansowe to jest rzecz drugorzędna, nie rozmawia się już na pewno w kontekście wyceniania czyjegoś życia. Nigdy nie nauczyłam się negocjować własnej pensji. Ale sąd nie wziął pod uwagę kontekstu. Zasądził ode mnie 9 tys. zł plus koszty procesowe".

Na to dziennikarka zapytała, czy dziś, po sprzeciwie NFZ i wyroku sądu, rozmówczyni leczyłaby tamtych pacjentów inaczej? Lekarka odpowiedziała:

„Leczyłabym ich tak samo jak wtedy. W onkologii, jeśli choroba jest bardzo zaawansowana, przedłużenie komuś życia o sześć miesięcy bywa wielkim osiągnięciem, nawet jeśli z bardziej oddalonej perspektywy wydanie na to kilkudziesięciu tysięcy złotych uzna się za nieopłacalne. W moim pojęciu to tylko pacjent może zdecydować, ile to jest dla niego pół roku i czy chce o te pół roku zawalczyć. Brak działania ze strony lekarza również jest formą działania, do którego nie ma on prawa. Na tym polega jego odpowiedzialność"11.

Zdajmy sobie sprawę, że jeżeli ograniczymy usługi publiczne poniżej pewnego poziomu (oczywiście dyskusyjne jakiego), to wejdziemy na drogę rozsypania się niejednej instytucji i zagrożenia spójności społeczeństwa.

Swego czasu św. Bernard zarzucał mistrzom handel wiedzą, a więc tym, co - według niego - należało jedynie do Boga i co było bezpłatne w szkołach klasztornych ${ }^{12}$. Nie postuluję pójścia za jego wskazaniami, zwłaszcza że ani ja, ani - jak przypuszczam — żaden z kolegów, nie mamy predyspozycji do bycia zakonnikami. Nie postuluję też, iżby na przykład lekarze w normalnych, a nie wyjątkowych sytuacjach mieli pracować dla idei lub za grosze. Niech mi będzie jednak wolno zakończyć te rozważania obserwacją, że społeczeństwo, które bezpardonowo sprowadzi życie do pieniędzy, pójdzie drogą bardzo ryzykowną. Są granice tego, co powinno być liczone w pieniądzach. W sprawach rozwoju gospodarczego i społecznego pieniądz jest instrumentem. Społeczeństwa, które

11 Nieodwracalna utrata spokoju. Rozmowa $z$ Agnieszka Jagietto-Gruszfeld, onkologiem, o rozterkach wrażliwego lekarza [rozmawiała Martyna Bunda], „Polityka”, 8 maja 2010.

12 Jacques Le Goff, Une vie pour l'histoire. Entretiens avec Marc Heurgon, Éditions La Découverte, Paris 1996, s. 86. 
tego nie zauważyły, nieraz w dziejach weszły w kryzysy gospodarcze, wstrząsy społeczne oraz dopuściły do degradacji środowiska.

\section{MONEY AS CULTURAL PHENOMENON}

\section{Summary}

The author reflects on the evaluation of the notion of money in history. In many situations coins and banknotes were a proof for the existence of local, independent, political power. People's attitude toward money was quite an important matter, too; in many situations neither money nor those professionally dealing with money were appreciated socially. Numerous utopian movements disliked money. Communism was one of them. The communist economy was driven - at least in theory - by overwhelming planning rather than by the incentive of money. After the fall of communism a question arised whether all or nearly all public activity should be driven by money or whether some domains of social activity should rather be kept as public domains.Key words / słowa kluczowe

\section{Key words/słowa kluczowe}

money / pieniądze; coins / monety; the attributes of power / atrybuty władzy; communism / komunizm 